\title{
Study of Wheat Response to Nitrogen Fertilization, Micronutrients and their Effects on Some Soil Available Macronutrients
}

\author{
S.E.D. Faizy, S.A. Mashali (deceased), S.M. Youssef and Shaimaa M. Elmahdy \\ Soil and Water Dept., Faculty of Agriculture, Kafrelsheikh Univ., Kafrelsheikh, Egypt.
}

\begin{abstract}
THE PRESENT investigation was carried out in the Experimental Farm of Faculty of Agriculture, Kafr El-Sheikh University during the two successive winter growing seasons of 20122013/and 20132014/ in the same location to study the long term effect using one variety of wheat (Triticum aestivum L.), cv. Masr 1. The experiment was conducted in split-split plot design, with four replicates. The main plots were randomly assigned to nitrogen levels $(0,40$ and $80 \mathrm{~kg} \mathrm{~N} / \mathrm{fed}$ ), the sub plots were represented by the two chelated forms of humic and EDTA as foliar application and the sub-sub plots were represented by four micronutrients spraying of $\mathrm{Fe}, \mathrm{Cu}, \mathrm{Mn}$ and $\mathrm{Zn}$, each one in two concentrations. The objectives of the present study were to investigate the effect of different levels of $\mathrm{N}$ and foliar application of some chelated micronutrients on: (1) grain yield and yield component of wheat plant (2) uptake of N, P and $\mathrm{K}$ by wheat under different treatment of $\mathrm{N}$ rates and micronutrients and (3) some soil available macronutrients. The results showed that, the best treatments were $\mathrm{N}_{80}, \mathrm{Zn}_{2}$ and $\mathrm{Mn}_{2}$ which gave the highest production for wheat grain and straw yield which indicate the importance of balance fertilization for wheat crop. These results also indicated that, improving soil fertility and replenishment nutrients depletion under the conditions of the present study could be achieved using previous treatments.
\end{abstract}

Keywords: Wheat, Nitrogen, Zinc, Copper, Manganese, Iron

\section{Introduction}

Wheat (Triticum aestivum L.) is considered the major cereal crop in the world in respect of the cultivated area and total production. It provides an almost 20\% of food energy for people in Egypt. Increasing wheat production is the ultimate goal to reduce the wide gap between production and consumption which amount to $40 \%$ of production. Nitrogen plays a key role in this plant nutrition. Nitrogen required in the greatest quantity by cereal crops. As a result of its critical role and low supply the management of $\mathrm{N}$ resources is an extremely important aspect of crop production (Sebastiano et al., 2005). Foliar fertilization of urea and potassium cause a significant stimulatory effect on growth parameters using foliar feeding at 65, 90 and 115 days after sowing (Mahmed et al., 2010). Nitrogen is applied in order to increase yield and improve crop quality. Nitrogen fertilization contributes significantly to protein content (Ames et al., 2003).

Labuschagne et al. (2006) concluded that $\mathrm{N}$ fertilizer rate and the time of application affects the fractional composition of proteins. Increasing fertilizer level up to $90 \mathrm{~kg} \mathrm{~N} /$ fed significantly increased yield and yield components compared with lower fertilizer levels and the control .Also, foliar application with mixture of micronutrients in addition to fertilizing with $90 \mathrm{~kg} \mathrm{~N} \mathrm{fed}{ }^{-1}$ can maximize wheat grain and straw yields and gave the best quality parameter of grains (Seadh et al., 2009). On the other hand, increasing nitrogen fertilizer rates $(75,100,125 \mathrm{~kg} \mathrm{~N} /$ feddan) resulted in significant increase in grain yield, straw yield and biological yield (Ibrahim et al., 2014).

Micronutrients play key roles in the release of carbon dioxide, and in optimizing the function of vitamin $A$ and the immune system, as stated by Marschner (1995). Zinc ( $\mathrm{Zn})$ is known to have an important role either as a metal component of enzymes or as a functional, structural or regulatory cofactor of a large number of enzymes (Grotz \& Guerinot 2006 and Cakmak, 2008). Grain yield, straw yield, 1000-grain weight and number of grains/spike, Fe, Mn and $\mathrm{Zn}$ concentration in flag leaves and grains as well as protein content in grain 
were significantly increased by application of these elements (Zeidan et al., 2010). Zinc is an essential micronutrient, which its deficiency is common in wheat growing areas of the world particularly in alkaline soils. In alkaline soils, $\mathrm{Zn}$ is fixed or precipitated in unavailable forms. Specially in wheat, improvement yield and yield components were affected by foliar application of zinc, boron and copper (Daneshbakhsh et al., 2013). Also the foliar application with the combination of micronutrients $(\mathrm{Cu}+\mathrm{Fe}+\mathrm{Mn}+\mathrm{Zn})$ produce the highest values of plant height, tillers number, spikes number, spike length, number of spikelets spike $^{-1}$, number of grains spike ${ }^{-1}, 1000$-grain weight, grain yield, straw yield, biological yield and harvest index (Mekkei and El-Haggan, 2014). The micronutrients content in wheat grains and straw positively correlated with silt, clay, organic carbon and CEC and negatively correlated with sand, $\mathrm{CaCO}_{3}$ and $\mathrm{pH}$ of soils (Kumar, 2011). Humic acid might benefit plant growth by chelating unavailable nutrients and buffering $\mathrm{pH}$ (Julie \& Bugbee 2006 and Zancani et al., 2009). The functional groupings of the humic substances act as acids or bases, as anion and cation changers and specific absorbent for the nutritive and harmful substances. Also increasing humic acid at rate $4 \mathrm{~kg} /$ fed with $\mathrm{Zn}$ and $\mathrm{Mn}$ mixture produced the highest mean values of growth (Radwan et al., 2015). The aim of this work was to study the effect of three nitrogen fertilizer levels soil application and some micronutrients ( $\mathrm{Fe}, \mathrm{Cu}, \mathrm{Mn}$ and $\mathrm{Zn}$ ) adding in two chelated forms of humic and EDTA as foliar application on soil properties, wheat yield and its components.

\section{Materials and Methods}

Two field experiments were carried out at the Experimental Farm of Faculty of Agriculture, Kafr El-Sheikh University, Kafr El-Sheikh Governorate, during the two successive winter growing seasons of 20122013/ and 20132014/ at the same location to study the long term effect using one variety of wheat (Triticum aestivum L.), cv. Misr 1. The wheat seeds were obtained kindly from the Agricultural Research Station, Sakha, Kafr El-Sheikh, Egypt to study the effect of three nitrogen fertilizer levels soil application and some micronutrients ( $\mathrm{Fe}, \mathrm{Cu}, \mathrm{Mn}$ and $\mathrm{Zn}$ ) adding in two chelated forms of humic and EDTA as foliar application on soil properties, wheat growth, yield and its components. Split-split plot design, with four replicates was the experimental design. The main plots were randomly assigned to three nitrogen levels $(0,40$, and $80 \mathrm{~kg} \mathrm{~N} / \mathrm{fed})$, the sub plots were subjected to two forms of chelates for the micronutrients added as foliar application i.e., EDTA and humic.

The sub-sub plots were represented by two concentration of four micronutrients spraying solution of $\mathrm{Fe}, \mathrm{Cu}, \mathrm{Mn}$ and $\mathrm{Zn}$ as a sulphate form (200 and $300 \mathrm{mg} \mathrm{L}^{-1}$ for Fe, 70 and $100 \mathrm{mg} \mathrm{L}^{-1}$ for $\mathrm{Mn}, 30$ and $50 \mathrm{mg} \mathrm{L}^{-1}$ for $\mathrm{Zn}, 30,50 \mathrm{mg} \mathrm{L}^{-1}$ for $\mathrm{Cu}$ ) in addition to control without spraying. Micronutrients were sprayed twice, the first at the tillering stage (35 days from sowing) and the second one at the booting stage (70 days from sowing). The area of each plot was $7.5 \mathrm{~m}^{2}(2.5 \times$ $3 \mathrm{~m})$. Nitrogen was added as ammonium nitrate $(33.5 \% \mathrm{~N})$, on three doses, the first dose $(20 \%)$ at sowing, the second dose $(50 \%)$ at the first irrigation ( 25 day from sowing), the third dose $(30 \%)$ at the following irrigation (53 days from sowing). Phosphorus was applied as mono super phosphate $\left(15.5 \% \mathrm{P}_{2} \mathrm{O}_{5}\right)$ at the rate of $15.5 \mathrm{~kg}$ $\mathrm{P}_{2} \mathrm{O}_{5}$ fed $^{-1}$ during the soil preparation. Potassium was applied as potassium sulphate $\left(48 \% \mathrm{~K}_{2} \mathrm{O}\right)$ at the rate $24 \mathrm{~kg} \mathrm{~K}_{2} \mathrm{O}$ fed $^{-1}$ at the first irrigation. The other agricultural practices were done as the recommendation of Ministry of Agriculture. The Collected soil samples were air dried, grinded, passed through a $2 \mathrm{~mm}$ sieve and thoroughly analyzed for some selected chemical properties (Page et al., 1982). The soil main characteristics, before planting of the two seasons, were represented in Table 1. The residual N, P and K after growing seasons were done according to Faizy et al. (2012). Plant samples were collected at the end of the experiment, oven dried at $70{ }^{\circ} \mathrm{C}$, grinded and wet digested using sulphoric-perchloric acids mixture (Chapman and Pratt 1961). Nitrogen content was determined in the digested solution using micro-Kjeldahl method (Page et al., 1982). Phosphorus was calorimetrically measured according to Snell and Snell (1967). Potassium was determined according to Jackson (1967). 
TABLE 1. Physical and chemical analyses of the experimental soil $(0-50 \mathrm{~cm})$ before planting in the two seasons 2012/2013 and 2013/2014

\begin{tabular}{|c|c|c|c|c|}
\hline \multirow[t]{2}{*}{ Parameters } & \multicolumn{2}{|c|}{ First season 2012/2013 } & \multicolumn{2}{|c|}{ Second season 2013/2014 } \\
\hline & $0-25 \mathrm{~cm}$ & $25-50 \mathrm{~cm}$ & $0-25 \mathrm{~cm}$ & $25-50 \mathrm{~cm}$ \\
\hline Soil pH ( $1: 2.5$ soil water suspension $)$ & 8.10 & 8.50 & 7.95 & 8.30 \\
\hline $\mathrm{EC}, \mathrm{dS} \mathrm{m}^{-1}$ at $25^{\circ} \mathrm{C}^{*}$ & 5.20 & 4.60 & 4.50 & 4.70 \\
\hline Total carbonate, \% & 2.97 & 3.47 & 4.83 & 4.91 \\
\hline $\mathrm{SP}(\%)$ & 85.05 & 82.76 & 98.21 & 93.40 \\
\hline $\mathrm{CEC}, \mathrm{cmol} / \mathrm{kg}$ soil & 42.00 & 38.50 & 35.00 & 32.00 \\
\hline \multicolumn{5}{|c|}{ Particle size distribution (\%) and texture class } \\
\hline Clay & 52.00 & 50.20 & 48.49 & 52.80 \\
\hline Silt & 23.80 & 27.60 & 28.60 & 26.70 \\
\hline Sand & 24.20 & 22.20 & 22.91 & 20.50 \\
\hline Soil texture class & Clayey & Clayey & Clayey & Clayey \\
\hline Organic matter $\left(\mathrm{g} \mathrm{kg}^{-1}\right)$ & 18.2 & 16.5 & 16.5 & 11.7 \\
\hline \multicolumn{5}{|c|}{ Soluble cations and anions, $\mathrm{meq} / \mathrm{L}$} \\
\hline $\mathrm{Ca}^{++}$ & 1355 & 1730 & 1520 & 1640 \\
\hline $\mathrm{Mg}^{++}$ & 2.94 & 4.25 & 2.74 & $\begin{array}{l}10.40 \\
4.10\end{array}$ \\
\hline $\mathrm{Na}^{+}$ & 35.56 & 23.91 & 26.80 & 26.50 \\
\hline $\mathrm{K}^{+}$ & 0.85 & 0.87 & 0.80 & 0.78 \\
\hline $\mathrm{CO}_{3}=$ & ND & ND & ND & ND \\
\hline $\mathrm{HCO}_{3}^{-}$ & 5.10 & 4.81 & 4.74 & 4.40 \\
\hline $\mathrm{Cl}^{-}$ & 17.81 & 24.60 & 27.50 & 29.20 \\
\hline $\mathrm{SO}_{4}=$ & 29.99 & 16.92 & 13.3 & 14.18 \\
\hline \multicolumn{5}{|c|}{ Available DTPA micronutrients, $\mathrm{mg} \mathrm{kg}^{-1}$} \\
\hline $\mathrm{Cu}$ & 2.80 & 0.98 & 3.10 & 4.70 \\
\hline $\mathrm{Fe}$ & 1.18 & 2.60 & 3.24 & 3.82 \\
\hline Mn & 4.30 & 4.80 & 5.20 & 4.01 \\
\hline $\mathrm{Zn}$ & 1.04 & 1.23 & 0.68 & 0.84 \\
\hline \multicolumn{5}{|c|}{ Available macronutrients, $\mathrm{mg} \mathrm{kg}^{-1}$} \\
\hline $\mathrm{N}$ & 38.50 & 31.00 & 28.20 & 20.80 \\
\hline $\mathrm{P}$ & 18.00 & 15.60 & 21.00 & 17.30 \\
\hline K & 420.00 & 394.00 & 463.00 & 419.00 \\
\hline Total Nitrogen, $\%$ & 0.08 & 0.12 & 0.12 & 0.16 \\
\hline
\end{tabular}

Abbreviations: ND: Not detected, EC*: in soil paste extract, SP\%: saturation percent, CEC: cation exchange capacity, OM: organic matter

\section{Results and Discussion}

Grain yield, straw yield and 1000 grain weight of wheat

Data presented in Table 2 show that, increasing nitrogen fertilizer levels from 0 to 40 and $80 \mathrm{~kg}$ $\mathrm{N}$ / fed significantly increased wheat grain yield $\left(\right.$ ardab fed $\left.{ }^{-1}\right)$, straw yield $\left(\right.$ ton fed $\left.{ }^{-1}\right)$ and 1000 grain weight $(\mathrm{g})$. The highest grain values (23.70 and 24.31) were in the first and second season. The straw yield ranged from 3.5 to 3.8 ton $\mathrm{fed}^{-1}$ in the first and second season, respectively. The highest 1000 grain weight were obtained with the $80 \mathrm{~kg}$ $\mathrm{N}$ fed ${ }^{-1}$ treatment, it may be due to the effect of $\mathrm{N}$ which was one of the major macronutrients for the plants, which plant structural and functional protein. On the other hand the lowest values were obtained with control the treatment. The trend of obtained these data are agree with those obtained by Sebastiano et al. (2005) and Ahmed et al. (2011) who concluded that nitrogen plays a key role in plant nutrition. The management of $\mathrm{N}$ is an extremely important of crop production. In respect to form of tested chelates, data in Table 2 show that humic was significantly effects higher on grain yield (16.08 and 16.55 ardab fed ${ }^{1}$ ), straw yield (3.32 and 3.06 ton $\left.\mathrm{fed}^{-1}\right)$ and 1000 grain weight (49.15 and $47.51 \mathrm{gm}$ ) in the first and second seasons, respectively, obtained the values with EDTA form. Similar trends were reported by El-Saady, (2012) and Gad El-Hak et al. (2012). 
TABLE 2. Effect of nitrogen fertilizer rates, forms of chelated and different micronutrients concentration on amounts of grain yield, straw yield and 1000 grain weight of wheat

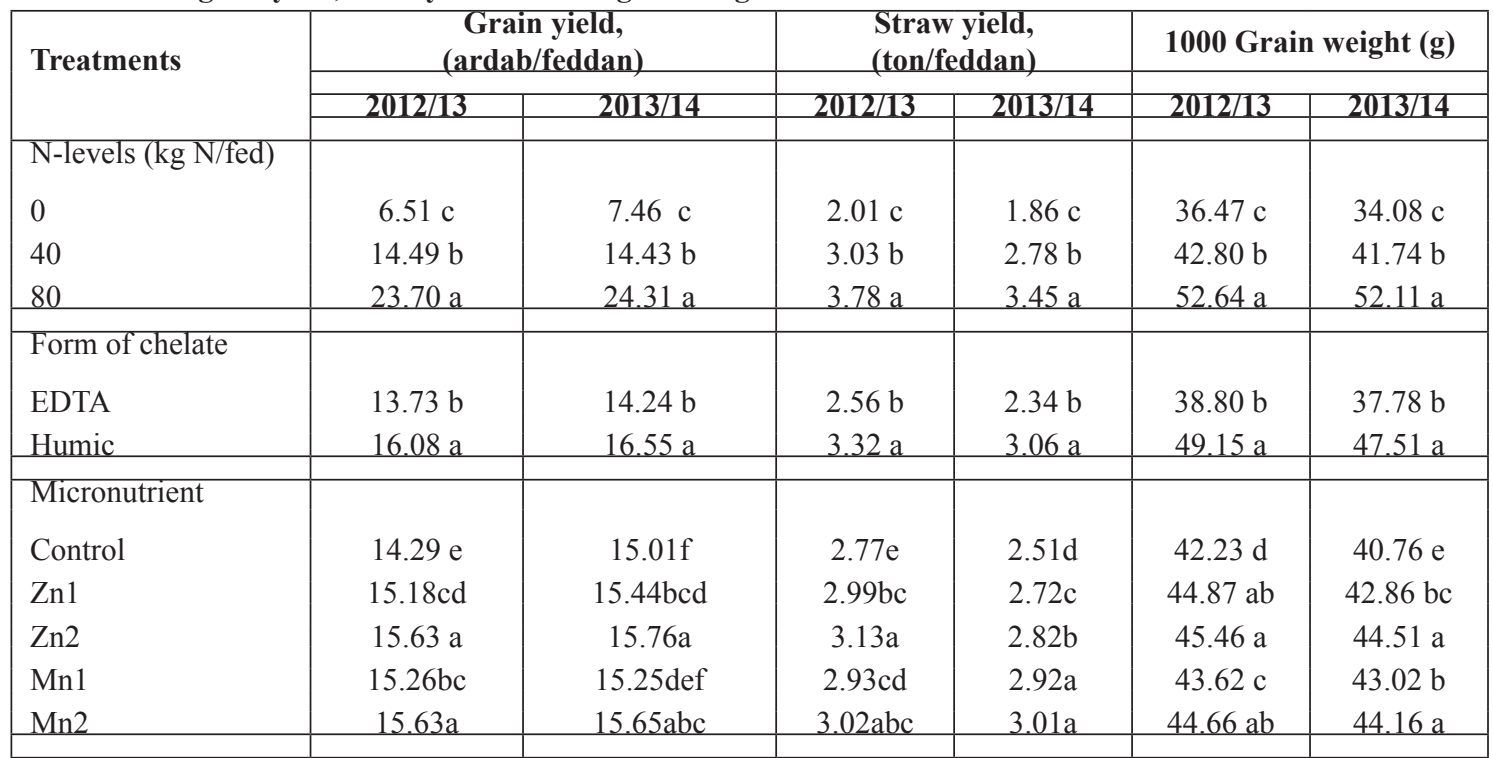

Ardab $=150 \mathrm{Kg}, \mathrm{Fe}_{1}=200 \mathrm{mg} / \mathrm{L}, \mathrm{Fe}_{2}=300 \mathrm{mg} / \mathrm{L}, \mathrm{Mn}_{1}=70 \mathrm{mg} / \mathrm{L}, \mathrm{Mn}=100 \mathrm{mg} / \mathrm{L}$, $\mathrm{Zn}_{1}=30 \mathrm{mg} / \mathrm{L}, \mathrm{Zn}_{2}=50 \mathrm{mg} / \mathrm{L}, \mathrm{Cu}_{1}=30 \mathrm{mg} / \mathrm{L}, \mathrm{Cu}_{2}=50 \mathrm{mg} / \mathrm{L}$.

Micronutrients spraying significantly affected wheat grain and straw yields as well as yield components (Table 2). The highest grain yield in the first and second season were obtained with spray $\mathrm{Zn}{ }_{2}\left(15.63\right.$ and $\left.15.76 \mathrm{ardab}^{-\mathrm{fed}^{-1}}\right)$. The highest straw yield $\left(3.13\right.$ ton $\left.\mathrm{fed}^{-1}\right)$ in the first season was obtained with $\mathrm{Zn}_{2}$ while in the second season 3.02 ton fed $^{-1}$ with $\mathrm{Mn}_{2}$. The highest values of 1000-grain weight (45.46 and 44.51gm) were obtained with $\mathrm{Zn}_{2}$. It may be affected by decreasing of soil available $\mathrm{Zn}$ to plant need. The high response of wheat yield components to $\mathrm{Zn}$, suggests the importance of this element to wheat cultivation in north delta soils. Similar trends were reported by Cakmak (2008), Zeidan et al. (2010) and Daneshbakhsh et al. (2013).

$N$-concentration (\%) in grain and straw yield of wheat

Data presented in Table 3 show that, increasing Nitrogen fertilizer levels produced a significant affected on wheat grain in both tested seasons. Obvious increase of grain $\mathrm{N}$ percentage was detected with increasing nitrogen fertilizer levels to $80 \mathrm{Kg} \mathrm{N} \mathrm{fed}^{-1}$. The highest $\mathrm{N} \%$ (2.01 and 2.02\%) in the first and second season, respectively were obtained with $80 \mathrm{Kg} \mathrm{N}^{-1} \mathrm{f}^{-1}$, where the increasing $\mathrm{N}$ levels led to increase the available $-\mathrm{N}$ to plants the obtained of these results were agree with those obtained by Gholami et al. (2011) and Woyema et al. (2012). A significant effect was observed with the $\mathrm{N}$ percent in grain and straw of wheat in both seasons (Table 3). Application of humic was increased the N\% values (1.74 and $1.78 \%$ ) in grains and $(0.43$ and $0.37 \%)$ in the straw . where the organic substances enhance plant absorption of the nutrients. Similar trends were reported by Khaled \& Hassan (2011), El- Bassiouny et al. (2014) and Wojlkowiak et al. (2014).

Zinc significantly increased Nitrogen percent of wheat grain (1.69 and $1.69 \%$ ) in both seasons .Also, this high nitrogen content might indicate meet the protein content in grains yield an this is very important to Egypt because it increase the nutrition on value of grains in comparison with meet protein $\mathrm{N} \%$ in wheat straw significantly affected by micronutrients type and its concentration, where $\mathrm{Mn}$, had the highest N\% of wheat straw $(0.67$ and $0.35 \%)$ in the first and second season, respectively. Similar trends were reported by Potarzycki \& Grzebisz (2009), ElFouly et al. (2011) and El- Saady (2012) who concluded that zinc exerts a great influence on basic plant life processes such as nitrogen metabolism, uptake of $\mathrm{N}$ and protein quality and photosynthesis. This is an important result with respect to show as it increases the protein content of the main feed of animals in Egypt. 
TABLE 3. Effect of nitrogen fertilizer rates forms of chelated and different micronutrients concentration on $\mathrm{N}$-percentage in grain and straw yield of wheat plants

\begin{tabular}{|c|c|c|c|c|}
\hline \multirow[b]{2}{*}{ Treatments } & \multicolumn{2}{|c|}{$\mathrm{N}$-concentration in grain (\%) } & \multicolumn{2}{|c|}{$\mathrm{N}$-concentration in straw (\%) } \\
\hline & $2012 / 13$ & 2013/14 & $2012 / 13$ & 2013/14 \\
\hline N-level (Kg N/fed) & & & & \\
\hline 0 & $1.290 \mathrm{c}$ & $1.354 \mathrm{c}$ & $0.3074 \mathrm{~b}$ & $0.3157 \mathrm{c}$ \\
\hline 40 & $1.605 \mathrm{~b}$ & $1.617 \mathrm{~b}$ & $0.3476 \mathrm{ab}$ & $0.3476 \mathrm{~b}$ \\
\hline 80 & $2.011 \mathrm{a}$ & $2.022 \mathrm{a}$ & $0.3778 \mathrm{a}$ & $0.3828 \mathrm{a}$ \\
\hline Form of chelate & & & & \\
\hline EDTA & $1.53 b$ & $1.55 b$ & $0.32 b$ & $0.33 b$ \\
\hline Humic & $1.74 \mathrm{a}$ & $1.78 \mathrm{a}$ & $0.43 a$ & $0.37 \mathrm{a}$ \\
\hline Micronutrient content & & & & \\
\hline Control & $1.593 \mathrm{~d}$ & $1.593 \mathrm{~d}$ & $0.3250 \mathrm{~b}$ & $0.3289 \mathrm{~d}$ \\
\hline $\mathrm{Zn} 1$ & $1.682 \mathrm{a}$ & $1.682 \mathrm{a}$ & $0.3439 \mathrm{~b}$ & $0.3533 \mathrm{ab}$ \\
\hline $\mathrm{Zn} 2$ & $1.695 \mathrm{a}$ & $1.695 \mathrm{a}$ & $0.3450 \mathrm{~b}$ & $0.3539 \mathrm{ab}$ \\
\hline Mn1 & $1.683 \mathrm{a}$ & $1.683 \mathrm{a}$ & $0.3400 \quad b$ & $0.3489 \mathrm{bc}$ \\
\hline $\mathrm{Mn} 2$ & $1.689 \mathrm{a}$ & $1.689 \mathrm{a}$ & $0.6789 \mathrm{a}$ & $0.3567 \mathrm{a}$ \\
\hline
\end{tabular}

$\mathrm{Fe}_{1}=200 \mathrm{mg} / \mathrm{L}, \mathrm{Fe}_{2}=300 \mathrm{mg} / \mathrm{L}, \mathrm{Mn}_{1}=70 \mathrm{mg} / \mathrm{L}, \mathrm{Mn}_{2}=100 \mathrm{mg} / \mathrm{L}$,

$\mathrm{Zn}_{1}=30 \mathrm{mg} / \mathrm{L}, \mathrm{Zn}_{2}=50 \mathrm{mg} / \mathrm{L}, \mathrm{Cu}_{1}=30 \mathrm{mg} / \mathrm{L}, \mathrm{Cu}_{2}=50 \mathrm{mg} / \mathrm{L}$.

$P$-concentration in grain and straw yield of wheat

Data presented in Table 4 show that, nitrogen fertilizer levels high significantly affected of $\mathrm{P} \%$ in wheat grain in the second season only. In the second season, Increasing of grain $\mathrm{P} \%$ was detected with increasing nitrogen fertilizer levels to $80 \mathrm{~kg} \mathrm{~N}$ fed $^{-1}$. The highest $\mathrm{P}$ content $(0.41 \%)$ in the second season only were obtained with $80 \mathrm{Kg}$ $\mathrm{N}$ fed ${ }^{-1}$.this may be due to increasing $\mathrm{N}$ levels led to stimulating effect of $\mathrm{N}$ and $\mathrm{P}$ this might be due to the long term effect of adding $\mathrm{P}$ in the second year. Straw P\% was highly significant in the first season than the second season. The obtained data were agreed with those obtained by Ahmed et al. (2011) and Jamal et al. (2006). Chelate forms significantly affected $\mathrm{P} \%$ of wheat in the second season of wheat grain and the first season of wheat straw as shown in Table 4. The humic effect of on $\mathrm{P} \%$ was higher in the grain and straw in the first season only. Similar trends were reported by Khaled \& Hassan (2011) and El- Bassiouny et al. (2014). Manganese significantly increased $\mathrm{P} \%$ of wheat grain $(0.38 \%)$ in the second season only. Phosphorus \%of wheat straw was not significant in both seasons. The same trends were reported by El-Saady (2012) and El-Fouly et al. (2011).

TABLE 4. Effect of nitrogen fertilizers rates, forms of chelated and different micronutrients concentration on $P$-percentage in grain and straw yield of wheat plants

\begin{tabular}{|l|c|c|c|c|}
\hline \multirow{2}{*}{ Treatments } & \multicolumn{2}{|c|}{ P-concentration in grain (\%) } & \multicolumn{2}{c|}{ P-concentration in straw (\%) } \\
\cline { 2 - 5 } & $\mathbf{2 0 1 2 / 1 3}$ & $\mathbf{2 0 1 3 / 1 4}$ & $\mathbf{2 0 1 2 / 1 3}$ & $\mathbf{2 0 1 3 / 1 4}$ \\
\hline N-level Kg N/fed & & & & \\
0 & & $0.34 \mathrm{c}$ & $0.10 \mathrm{c}$ & $0.10 \mathrm{a}$ \\
40 & $0.43 \mathrm{a}$ & $0.36 \mathrm{~b}$ & $0.11 \mathrm{~b}$ & $0.11 \mathrm{a}$ \\
80 & $0.43 \mathrm{a}$ & $0.42 \mathrm{a}$ & $0.13 \mathrm{a}$ & $0.35 \mathrm{a}$ \\
\hline Form of chelate & & & & \\
Humic & $0.44 \mathrm{a}$ & $0.40 \mathrm{a}$ & $0.12 \mathrm{a}$ & $0.13 \mathrm{a}$ \\
EDTA & $0.43 \mathrm{a}$ & $0.41 \mathrm{a}$ & $0.13 \mathrm{a}$ & $0.12 \mathrm{a}$ \\
\hline Micronutrient conc. & & & & \\
Control & & & & \\
Mn1 & $0.35 \mathrm{~b}$ & $0.35 \mathrm{c}$ & $0.10 \mathrm{~b}$ & $0.10 \mathrm{~b}$ \\
Mn2 & $0.38 \mathrm{~b}$ & $0.38 \mathrm{ab}$ & $0.11 \mathrm{a}$ & $0.12 \mathrm{~b}$ \\
\hline
\end{tabular}

$\mathrm{Fe}_{1}=200 \mathrm{mg} / \mathrm{L}, \mathrm{Fe}_{2}=300 \mathrm{mg} / \mathrm{L}, \mathrm{Mn}_{1}=70 \mathrm{mg} / \mathrm{L}, \mathrm{Mn}_{2}=100 \mathrm{mg} / \mathrm{L}$, 
K-concentration (\%) in grain and straw yield of wheat

Data presented in Table 5 showed that, nitrogen fertilizer levels high significantly affected $\mathrm{K}$ content of wheat grains in both tested seasons. Obvious increase of grain $\mathrm{K}$ content was detected with increasing nitrogen fertilizer levels to $80 \mathrm{Kg} \mathrm{N} \mathrm{fed}^{-1}$. The highest $\mathrm{K}$ percent in wheat grains $(0.49$ and $0.50 \%)$ in the first and second season, respectively were obtained under addition of $80 \mathrm{Kg} \mathrm{N}$ fed $^{-1}$. This effect it may be due to increasing $\mathrm{N}$ levels led to increase the availability of $\mathrm{K}$ to wheat plants. The highest $\mathrm{K} \%$ in wheat straw (1.28 and $1.49 \%$ ) were obvious in both two seasons. the trend of these obtained data were agree with those obtained by Gholami et al. (2011) and Woyema et al. (2012).
Chelated forms produced a significant affected on $\mathrm{K}$ - percentage of wheat grain and straw in both tested seasons Table (5). Humic exert the higher $\mathrm{K} \%(0.44$ and $0.45 \%)$ in grains and $(1.20$ and $1.43 \%$ ) in the straw yield. It may be due to humus stimulating effect on absorption of the nutrients. Similar trends were reported by Khaled \& Hassan (2011) and El-Bassiouny et al. (2014). Manganese application significantly increased K content of wheat grains $(0.43$ and $0.44 \%)$ in both tested seasons. Potassium percentage in wheat straw also significantly affected with type and concentrations of applied micronutrients. Also the highest $\mathrm{K}$ content of wheat straw (1.17 and $1.39 \%$ ) were in the first and second seasons under application of $\mathrm{Fe}_{2}$. Similar trends were detected by Potarzycki \& Grzebisz (2009), El-Fouly et al. (2011) and El-Saady (2012).

TABLE 5. Effect of nitrogen fertilizers rates, forms of chelated and different micronutrients concentration on K-percentage in grain and straw yield of wheat plants

\begin{tabular}{|c|c|c|c|c|}
\hline \multirow[b]{2}{*}{ Treatments } & \multicolumn{2}{|c|}{ K-concentration in grain (\%) } & \multicolumn{2}{|c|}{ K-concentration in straw (\%) } \\
\hline & $2012 / 13$ & $2013 / 14$ & $2012 / 13$ & $2013 / 14$ \\
\hline N-level Kg N/fed & & & & \\
\hline 0 & $0.33 \mathrm{c}$ & $0.36 \mathrm{c}$ & $1.00 \mathrm{c}$ & $1.23 \mathrm{c}$ \\
\hline 40 & $0.40 \mathrm{~b}$ & $0.41 \mathrm{~b}$ & $1.10 \mathrm{~b}$ & $1.37 \mathrm{~b}$ \\
\hline 80 & $0.49 \mathrm{a}$ & $0.50 \mathrm{a}$ & $1.28 \mathrm{a}$ & $1.49 \mathrm{a}$ \\
\hline Form of chelate & & & & \\
\hline EDTA & $0.44 \mathrm{a}$ & $0.45 \mathrm{a}$ & $1.20 \mathrm{a}$ & $1.43 \mathrm{a}$ \\
\hline Humic & $0.54 \mathrm{~b}$ & $0.55 \mathrm{~b}$ & $1.44 b$ & $1.55 \mathrm{~b}$ \\
\hline Micronutrient conc. & & & & \\
\hline Control & $0.36 \mathrm{e}$ & $0.37 \mathrm{~d}$ & $1.04 \mathrm{~b}$ & $1.27 \mathrm{c}$ \\
\hline $\mathrm{Fel}$ & $0.39 \mathrm{~d}$ & $0.41 \mathrm{c}$ & $1.15 \mathrm{a}$ & $1.36 \mathrm{~b}$ \\
\hline $\mathrm{Fe} 2$ & $0.40 \mathrm{c}$ & $0.42 \mathrm{~b}$ & $1.17 \mathrm{a}$ & $1.39 \mathrm{ab}$ \\
\hline Mn1 & $0.42 \mathrm{~b}$ & $0.43 \mathrm{a}$ & $1.12 \mathrm{a}$ & $1.37 \mathrm{ab}$ \\
\hline $\mathrm{Mn} 2$ & $0.43 \mathrm{a}$ & $0.44 \mathrm{a}$ & $1.15 \mathrm{a}$ & $1.39 \mathrm{a}$ \\
\hline
\end{tabular}

$\mathrm{Fe}_{1}=200 \mathrm{mg} / \mathrm{L}, \mathrm{Fe}_{2}=300 \mathrm{mg} / \mathrm{L}, \mathrm{Mn}_{1}=70 \mathrm{mg} / \mathrm{L}, \mathrm{Mn}_{2}=100 \mathrm{mg} / \mathrm{L}$, $\mathrm{Zn}_{1}=30 \mathrm{mg} / \mathrm{L}, \mathrm{Zn}_{2}=50 \mathrm{mg} / \mathrm{L}, \mathrm{Cu}_{1}=30 \mathrm{mg} / \mathrm{L}, \mathrm{Cu}_{2}=50 \mathrm{mg} / \mathrm{L}$.

Nitrogen, $P$ and $K$ uptake of wheat grain yield Nitrogen uptake

Data in Table 6 showed that N- uptake by grains were increased by about ( 86.18 and 87.23 $\mathrm{kg} / \mathrm{fed}$ ) in both tested seasons, as effected by increasing $\mathrm{N}$ levels up to $80 \mathrm{Kg} \mathrm{N} /$ fed .Similar trends were reported by Koch and Mengel (1977). Chelate forms significantly affected N-uptake of wheat grain in both seasons Table 6. Application of humic increased N-uptake values with grains (60.31 and $58.45 \mathrm{~kg} / \mathrm{fed}$ ) in the two growing seasons. Similar trends were reported by Kanani (1996). Also, Manganese application significantly increased N-uptake of wheat grain (63.71 and
$53.48 \mathrm{~kg} / \mathrm{fed}$ ) in both two growing seasons. Similar trends were reported by Potarzycki \& Grzebisz (2009), El-Fouly et al. (2011) and ElSaady (2012).

\section{Phosphorus uptake}

Data in Table 6 showed that P- uptake by grains were increased by about (20.14 and $19.97 \mathrm{~kg} / \mathrm{fed}$ ) in both two seasons as affected by increasing $\mathrm{N}$ addition up to $80 \mathrm{Kg} \mathrm{N} /$ fed .Similar trends were reported by Koch and Mengel (1977). Chelate forms significantly affected P-uptake of wheat grain in both seasons Table (6). Generally, the application of humic was increased P-uptake 
values with grains (15.32 and $14.13 \mathrm{~kg} / \mathrm{fed})$ in the two growing seasons than the EDTA form. Similar trends were reported by Kanani (1996). The application of $\mathrm{Mn}_{2}$ significantly increased P-uptake of wheat grain (17.99 and $12.84 \mathrm{~kg} / \mathrm{fed})$ in both seasons. Similar trends were reported by El-Fouly et al. (2011) and El-Saady (2012).

Potassiume uptake:

Data in Table (6) showed that K- uptake by grains was increased by about (22.38 and 69.77 $\mathrm{kg} / \mathrm{fed}$ ) in both growing seasons .affected by increasing $\mathrm{N}$ up to $80 \mathrm{Kg} \mathrm{N} / \mathrm{fed}$.Similar trends were reported by Khattab et al. (1996) Chelate forms significantly affected K-uptake of wheat grain in both seasons Table (6). On the other hand, the addition of humic was increased the uptake values of $\mathrm{N}$ grains (15.70 and $56.33 \mathrm{~kg} / \mathrm{fed}$ ) in the two growing seasons. Similar trends were reported by Kanani(1996). Application of $\mathrm{Mn}_{2}$ significantly increased K-uptake of wheat grain (14.54 and $53.84 \mathrm{~kg} / \mathrm{fed}$.) in both seasons. Similar trends were reported by El-Fouly et al. (2011) and El-Saady (2012).

TABLE 6. Effect of nitrogen fertilizers rates, forms of chelated and different micronutrients concentration on $\mathrm{N}, \mathrm{P}$ and $\mathrm{K}$ uptake of grain yield of wheat

\begin{tabular}{|c|c|c|c|c|c|c|}
\hline \multirow[b]{2}{*}{ Treatments } & \multicolumn{2}{|c|}{ N-uptake (kg/fed.) } & \multicolumn{2}{|c|}{ P-uptake (kg/fed.) } & \multicolumn{2}{|c|}{ K-uptake (kg/fed.) } \\
\hline & $2012 / 13$ & $2013 / 14$ & $2012 / 13$ & $2013 / 14$ & $2012 / 13$ & $2013 / 14$ \\
\hline N-level Kg N/fed & & & & & & \\
\hline 0 & $18.95 \mathrm{c}$ & $21.29 \mathrm{c}$ & $5.34 \mathrm{c}$ & $5.85 \mathrm{c}$ & $5.26 \mathrm{c}$ & $27.11 \mathrm{c}$ \\
\hline 40 & $49.32 \mathrm{~b}$ & $44.85 \mathrm{~b}$ & $12.95 \mathrm{~b}$ & $10.97 \mathrm{~b}$ & $12.24 \mathrm{~b}$ & $47.36 \mathrm{~b}$ \\
\hline 80 & $86.18 \mathrm{a}$ & $87.23 \mathrm{a}$ & $20.14 \mathrm{a}$ & $19.97 \mathrm{a}$ & $22.38 \mathrm{a}$ & $69.77 \mathrm{a}$ \\
\hline Form of chelate & & & & & & \\
\hline EDTA & $42.66 b$ & $43.79 b$ & $10.30 \mathrm{~b}$ & $10.40 \mathrm{~b}$ & $10.88 b$ & $39.82 b$ \\
\hline Humic & $60.31 \mathrm{a}$ & $58.45 \mathrm{a}$ & $15.32 \mathrm{a}$ & $14.13 \mathrm{a}$ & $15.70 \mathrm{a}$ & $56.33 a$ \\
\hline Micronutrient conc. & & & & & & \\
\hline Control & $45.83 \mathrm{~d}$ & $47.49 \mathrm{e}$ & $10.89 \mathrm{~b}$ & $10.85 \mathrm{c}$ & $11.05 \mathrm{f}$ & $41.44 \mathrm{f}$ \\
\hline Mn1 & $50.74 \mathrm{bcd}$ & $52.04 \mathrm{~b}$ & $12.65 \mathrm{~b}$ & $12.65 \mathrm{a}$ & $13.85 \mathrm{~b}$ & $51.84 \mathrm{~b}$ \\
\hline $\mathrm{Mn} 2$ & $63.71 \mathrm{a}$ & $53.48 \mathrm{a}$ & $17.99 \mathrm{a}$ & $12.84 \mathrm{a}$ & $14.54 \mathrm{a}$ & $53.84 \mathrm{a}$ \\
\hline
\end{tabular}

$\mathrm{Fe}_{1}=200 \mathrm{mg} / \mathrm{L}, \mathrm{Fe}_{2}=300 \mathrm{mg} / \mathrm{L}, \mathrm{Mn}_{1}=70 \mathrm{mg} / \mathrm{L}, \mathrm{Mn}_{2}=100 \mathrm{mg} / \mathrm{L}$,

$\mathrm{Zn}_{1}=30 \mathrm{mg} / \mathrm{L}, \mathrm{Zn}_{2}=50 \mathrm{mg} / \mathrm{L}, \mathrm{Cu}_{1}=30 \mathrm{mg} / \mathrm{L}, \mathrm{Cu}_{2}=50 \mathrm{mg} / \mathrm{L}$.

\section{Macronutrients (N, P and K) available of soil Available nitrogen in soil}

Data in Table (7) showed the values of Available -N after wheat harvesting. The highest value of available $-\mathrm{N}$ in both seasons were $(24.68$ $\mathrm{mg} \mathrm{N} / \mathrm{kg}$ and $24.65 \mathrm{mg} \mathrm{N} / \mathrm{kg}$ ) with $\mathrm{N}_{80}$ treatment .These data agree with those obtained by (Nasr ElDin 2001 and Alan et al. 2007). Available nitrogen was significantly affected by chelated forms after wheat harvesting in both seasons Table (7). Also, the addition of humic exert is more efficiency for increasing $\mathrm{N}$-available values (22.45 and 22.84 $\mathrm{mg} \mathrm{N} / \mathrm{kg}$ ) in the two growing seasons. Similar trends were reported by Potarzycki and Grzebisz (2009), El-Fouly et al. (2011) and El-Saady (2012). Addition of $\mathrm{Zn}_{2}$ increased $\mathrm{N}$-available after wheat harvesting (21.24 and $21.48 \mathrm{mg} \mathrm{N} / \mathrm{kg}$ ) in both seasons. Similar trends were reported by El-Fouly et al. (2011) and El-Saady (2012).
Available Phosphorus in soil

Data in Table 7 showed the values of soil Available P after wheat harvesting. The highest values of available $\mathrm{P}$ in both seasons were (17.83 $\mathrm{mg} \mathrm{P} / \mathrm{kg}$ and $15.92 \mathrm{mg} \mathrm{P} / \mathrm{kg}$ ) under $\mathrm{N}_{80}$ treatment. These results agree with those obtained by (Nasr El-din 2001 and Alan et al., 2007). Phosphorus available was affected significant by Chelated forms in both seasons (Table 7). Humic form exert a tendency to increase P-available values (14.12 and $12.97 \mathrm{mg} \mathrm{P} / \mathrm{kg}$ ) in the two growing seasons. Similar results were reported by ElFouly et al. (2011). The treatment of $\mathrm{Fe}_{2}$ was increased P-available significantly after wheat harvesting (13.79 and $12.12 \mathrm{mg} \mathrm{P} / \mathrm{kg}$ ) in both two seasons the amounts of available $\mathrm{P}$ in soil after wheat harvesting significantly affected by micronutrients type and concentration. Similar trends were reported by El-Fouly et al. (2011) and El-Saady (2012). 
Available Potassium in soil

Data in Table 7 showed the values of available $-\mathrm{K}$ in tested soil after wheat harvesting. The ranged from ( $287.19 \mathrm{mg} \mathrm{K} / \mathrm{kg}$ to $278.01 \mathrm{mg} \mathrm{K} /$ $\mathrm{kg}$ ) under $\mathrm{N}_{80}$ treatment. These trends were agree with those obtained by (Faizy et al., 2012) trends were reported by El-Fouly et al. (2011) and ElSaady (2012).
Application of different chelate forms significantly affected K-available after wheat harvesting in both seasons (Table 7). Potassium availability was significantly higher with humic forms $(266.34$ and $256.68 \mathrm{mg} \mathrm{K} / \mathrm{kg}$ ) in the two growing seasons. Similar trends were reported by El-Fouly et al. (2011). Application of $\mathrm{Fe}_{2}$ gave highly significant values of soil available-K after wheat harvesting $(261.1 \mathrm{mg} \mathrm{K} / \mathrm{kg})$ in the first season. Similar

TABLE 7. Effect of nitrogen fertilizers rates, forms of chelated and different micronutrients concentration on available $\mathrm{N}, \mathrm{P}$ and $\mathrm{K}$ of soil after wheat harvesting

\begin{tabular}{|c|c|c|c|c|c|c|}
\hline \multirow[t]{2}{*}{ Treatments } & \multicolumn{2}{|c|}{$\begin{array}{c}\text { Available nitrogen (mg/ } \\
\text { kg) }\end{array}$} & \multicolumn{2}{|c|}{$\begin{array}{c}\text { Available phosphorus } \\
\text { (mg/kg) }\end{array}$} & \multicolumn{2}{|c|}{$\begin{array}{c}\text { Available potassium } \\
(\mathrm{mg} / \mathrm{kg})\end{array}$} \\
\hline & $2012 / 13$ & $2012 / 13$ & $2012 / 13$ & $2013 / 14$ & $2013 / 14$ & $2013 / 14$ \\
\hline N-level Kg N/fed & & & & & & \\
\hline 0 & $17.85 \mathrm{c}$ & $18.52 \mathrm{c}$ & $9.17 \mathrm{c}$ & $7.89 \mathrm{c}$ & $217.35 c$ & $211.69 c$ \\
\hline 40 & $20.02 \mathrm{~b}$ & $20.36 \mathrm{~b}$ & $13.31 \mathrm{~b}$ & $12.16 b$ & $274.59 b$ & $258.76 b$ \\
\hline 80 & $24.68 \mathrm{a}$ & $24.65 \mathrm{a}$ & $17.83 \mathrm{a}$ & $15.92 \mathrm{a}$ & $287.19 \mathrm{a}$ & $278.01 \mathrm{a}$ \\
\hline Form of chelate & & & & & & \\
\hline EDTA & $19.25 \mathrm{~b}$ & $19.52 \mathrm{~b}$ & $12.74 \mathrm{~b}$ & $11.00 \mathrm{~b}$ & $253.08 \mathrm{~b}$ & $242.29 b$ \\
\hline Humic & $22.45 \mathrm{a}$ & $22.84 \mathrm{a}$ & $14.12 \mathrm{a}$ & $12.97 \mathrm{a}$ & $266.34 \mathrm{a}$ & $256.68 \mathrm{a}$ \\
\hline Micronutrient conc. & & & & & & \\
\hline Control & $19.58 \mathrm{c}$ & $19.72 \mathrm{~d}$ & $12.68 \mathrm{c}$ & $11.67 \mathrm{c}$ & $255.1 \mathrm{~d}$ & $243.6 \mathrm{ab}$ \\
\hline Fe1 & $20.92 \mathrm{ab}$ & $21.19 \mathrm{c}$ & $13.53 \mathrm{~b}$ & $12.07 \mathrm{a}$ & $260.2 \mathrm{ab}$ & $247.6 \mathrm{ab}$ \\
\hline $\mathrm{Fe} 2$ & $21.20 \mathrm{a}$ & $21.44 \mathrm{a}$ & $13.79 \mathrm{a}$ & $12.12 \mathrm{a}$ & $262.1 \mathrm{a}$ & $247.5 \mathrm{ab}$ \\
\hline $\mathrm{Zn} 1$ & $21.18 \mathrm{a}$ & $21.33 \mathrm{abc}$ & $13.48 \mathrm{~b}$ & $11.98 \mathrm{ab}$ & $261.4 \mathrm{ab}$ & $258.5 \mathrm{a}$ \\
\hline $\mathrm{Zn} 2$ & $21.24 \mathrm{a}$ & $21.49 \mathrm{a}$ & $13.52 \mathrm{~b}$ & $12.07 \mathrm{a}$ & $262.1 \mathrm{a}$ & $257.0 \mathrm{a}$ \\
\hline
\end{tabular}

$\mathrm{Fe}_{1}=200 \mathrm{mg} / \mathrm{L}, \mathrm{Fe}_{2}=300 \mathrm{mg} / \mathrm{L}, \mathrm{Mn}_{1}=70 \mathrm{mg} / \mathrm{L}, \mathrm{Mn}_{2}=100 \mathrm{mg} / \mathrm{L}$,

$\mathrm{Zn}_{1}=30 \mathrm{mg} / \mathrm{L}, \mathrm{Zn}_{2}=50 \mathrm{mg} / \mathrm{L}, \mathrm{Cu}_{1}=30 \mathrm{mg} / \mathrm{L}, \mathrm{Cu}_{2}=50 \mathrm{mg} / \mathrm{L}$.

\section{References}

Ahmed, G.A., Tawfik, M.M. and Hassanein MS (2011) Foliar Feeding of Potassium and Urea for Maximizing Wheat Productivity in Sandy Soil. Australian J. Basic Applied Sci., 5 (5), 11971203-.

Alan, L.W., Dou, F. and Hons, F.M. (2007) Soil organic $\mathrm{C}$ and $\mathrm{N}$ distribution for wheat cropping systems after 20 years of conservation tillage in central Texas. Agricultural, Ecosystem and Environment, 121, 376382-.

Ames, N.P., Clarke, J.M., Dexter, J.E., Woods, S.M., Selles, F. and Marchylo, B (2003) Effect of nitrogen fertilizer on protein quality and gluten strength parameters in durum wheat (Triticum turgidum $\mathrm{L}$. var. durum) cultivars of variable gluten strength. Cereal Chem., 80, 203211-.

Cakmak I (2008) Enrichment of cereal grains with zinc: Agronomic or genetic biofortification. Plant Soil 302, 117 -
Chapman, H.D. and Pratt P. F. (1961) Methods of Analysis for Soils, Plants and Water. Univ. of California, USA.

Daneshbakhsh, B., Khoshgoftarmanesh A. H., Shariatmadari H. and Cakmak I. (2013) Effect of zinc nutrition on salinity-induced oxidative damages in wheat genotypes differing in zinc deficiency tolerance. Acta Physiol Plant .35, 881889.

El-Saady, A. S. M. (2012) Impact of Foliar Spraying of Some Organic Substances and Micronutrients on Wheat Grown on Clayey Soil. J. Soil Sci. and Agric. Eng., Mansoura Univ., 3 (3), 349 - 360.

El-Bassiouny, H.S.M., Bakry, A.B., Abd El-Monem Attia, A. and Abd Allah, M.M. (2014) Physiological Role of Humic Acid and Nicotinamide on Improving Plant Growth, Yield, and Mineral Nutrient of Wheat (Triticum durum) Grown under Newly Reclaimed Sandy Soil. Agricultural Sciences, 5, 687700-. 
El-Fouly MM, Mobarak ZM and Salama AS. (2011) Micronutrients (Fe, Mn, Zn) Foliar Spray For Increasing Salinity Tolerance In Wheat Triticum Aestivum L. African J Plant Sci., 5(5), 314322-.

Faizy ,S.E.A., Rezk M.M., Gazia E.A.E. and Amer M.M.A. (2012) Effect of N, P and K Application Time on Yield And Uptake of Wheat Plants at North Delta. J. Soil Sci. and Agric. Eng., Mansoura Univ ., 3(8),791805-.

Gad El-Hak, S.H., A.M. Ahmed and Moustafa Y.M.M. (2012) Effect of Foliar Application with Two Antioxidants and Humic Acid on Growth, Yield and Yield Components of Peas (Pisum sativum L.) Journal of Horticultural Science \& Ornamental Plants 4 (3), 318328-.

Gholami, A., Akhlaghi S., Shahsavani S. and Farrokhi N. (2011) Effects of urea foliar application on grain yield and quali-ty of winter wheat. Commun. Soil Sci. Plant Anal. 42,719727-.

Grotz N. and Guerinot M.L. (2006) Molecular aspects of $\mathrm{Cu}, \mathrm{Fe}$ and $\mathrm{Zn}$ homeostasis in plants. Biochim. Biophys. Acta. 1763, 595-608.

Ibrahim, O.M., Bakry A.B., Thalooth A.T. and ElKaramany M.F. (2014) Influence of Nitrogen Fertilizer and Foliar Application of Salicylic Acid on Wheat. Agricultural Sciences, 5, 13161321-.

Jackson, M.L. (1967) Soil Chemical Analysis. Prentice Hall of India Ltd., New Delhi.

Jamal Z., Hamayun M., Ahmad N . and Chaudhry F.M. (2006) Effect of soil and Foliar Application of Different Concentrations of NPK and Foliar Application of (NH4)2SO4 on Different Yield Parameters in Wheat. J Agron., 5(2), 251256-.

Julie, C. and Bugbee B. (2006) The use of humic acid to ameliorate iron deficiency stress. Biol. Biochem., $2,6771-$

Kanani, R. E. E (1996) Effect of irrigation and fertilization on crop yield and nutrient uptake. Thesis ph. D. soil science, Fac. of Agric, Mansoura Univ.

Khaled H. and Hassan A. F. (2011) Effect of Different Levels of Humic Acids on the Nutrient Content, Plant Growth, and Soil Properties under Conditions of Salinity. Soil \& Water Res., 6 (1), 21-29.

Kock, K. and Mengel K. (1977) The effect of K on N fertilization by spring wheat during grain formation. Agron. J. 69, 477480-.
Kumar, M. and Babel A. L. (2011) Available Micronutrient Status and Their Relationship with Soil Properties of Jhunjhunu Tehsil, District Jhunjhunu, Rajasthan, India. Journal of Agricultural Science (19169752-), Jun, 3 (2), p97.

Labuschagne, M.T., Meintjes G. and Groenewald F.P.C. (2006) The influence of different nitrogen treatments on the size distribution of protein fractions in hard and soft wheat. Journal of Cereal Science 43, 315321-.

Mahmed, M. F., Thalooth A.T. and Khalifa H. M. (2010) Effect of Foliar Spraying with Uniconazole and Micronutrients on Yield and Nutrients Uptake of Wheat Plants Grown under Saline Condition. $J$. Amer Sci. 6(8), 398404-.

Marschner, H. (1995) Mineral Nutrition of Higher Plants, $2^{\text {nd }}$ ed., Academic Press, London

Mekkei, M. E. R. and El Haggan E. A. (2014) Effect of $\mathrm{Cu}, \mathrm{Fe}, \mathrm{Mn}, \mathrm{Zn}$ foliar application on productivity and quality of some wheat cultivars (Triticum aestivum L.). J. Agri-Food \& Appl. Sci., 2(9), 283291.

Nasr El-Din, I.E. (2001) Evaluation of some different soils from Kafr El-Sheikh under different crop patterns. Ph.D. Thesis. Fac. of Agric. Tanta Univ. Egypt.

Page, A.L., Miller R.H. and Keeney D.R. (1982)Methods of soil analysis chemical and microbiological properties. $2^{\text {nd }}$ Editions. Agronomy, V.G. ASA, SSSA Publishing, Madison, WI, p. 1159.

Potarzycki, J. and Grzebisz W. (2009) Effect of zinc foliar application on grain yield of maize and its yielding components. Plant Soil Environ., 55(12), 519527-.

Radwan, F. I., Gomaa, M. A., Ibrahem R F and Adam S. I. A. (2015) Impact of Humic Acid Application, Foliar Micronutrients and Biofertilization on Growth, Productivity and Quality of Wheat (Triticum aestivum, L.). Middle East Journal of Agriculture, 4 (2), 130140-

Seadh, S. E., EL-Abady M. I., El-Ghamry A. M. and Farouk S. (2009) Influence of Micronutrients Foliar Application and Nitrogen Fertilization on Wheat Yield and Quality of Grain and Seed. Journal of Biological Sciences, 9 (8), p. 851.

Sebastiano D., Tognetti R., Desiderio E. and Alvino A. (2005) Effect of foliar application of $\mathrm{N}$ and humic acids on growth and yield of durum wheat. Agronomy for Sustainable Development, Springer Verlag (Germany), 25 (2), 183191-. 
Snell, F.D. and Snell C.T. (1967) Colorimetric Methods of Analysis. D. Van. Nostrand Company Inc., pp. 551552-

Wojtkowiak, K., Stepien A., Warechowska M. and Raczkowski M. (2014) Content of copper, iron, manganese and zinc in typical light brown soil and spring triticale grain depending on a fertilization system. Journal of Elementology 19, 833844-.

Woyema A, Bultosa G. and Taa A . (2012) Effect Of Different Nitrogen Fertilizer Rates On Yield And Yield Related Traits For Seven Durum Wheat (Triticum Turgidum L. Var Durum) Cultivars Grown At Sinana, South Eastern Ethiopia. Scholarly, Peer Reviewed Volume 12 No. 3 May.
Zancani, M.E., Petressa K., Krajnakora J., Casolo V., Spaccini R., Piccolo A., Macri F. and Vianello A. (2009). Effect of humic acids on phosphatase level and energetic metabolism of tobacco BY-2 suspension cell culture. Environ. Exp. Bot., 65, 287295-

Zeidan, M.S., Mohamed M. F. and Hamouda H.A. (2010) Effect of Foliar Fertilization of Fe, Mn on Zn W heat Yield and Quality in Low Sandy Soils Fertility. World Journal of Agricultural Sciences 6 (6), 696699-
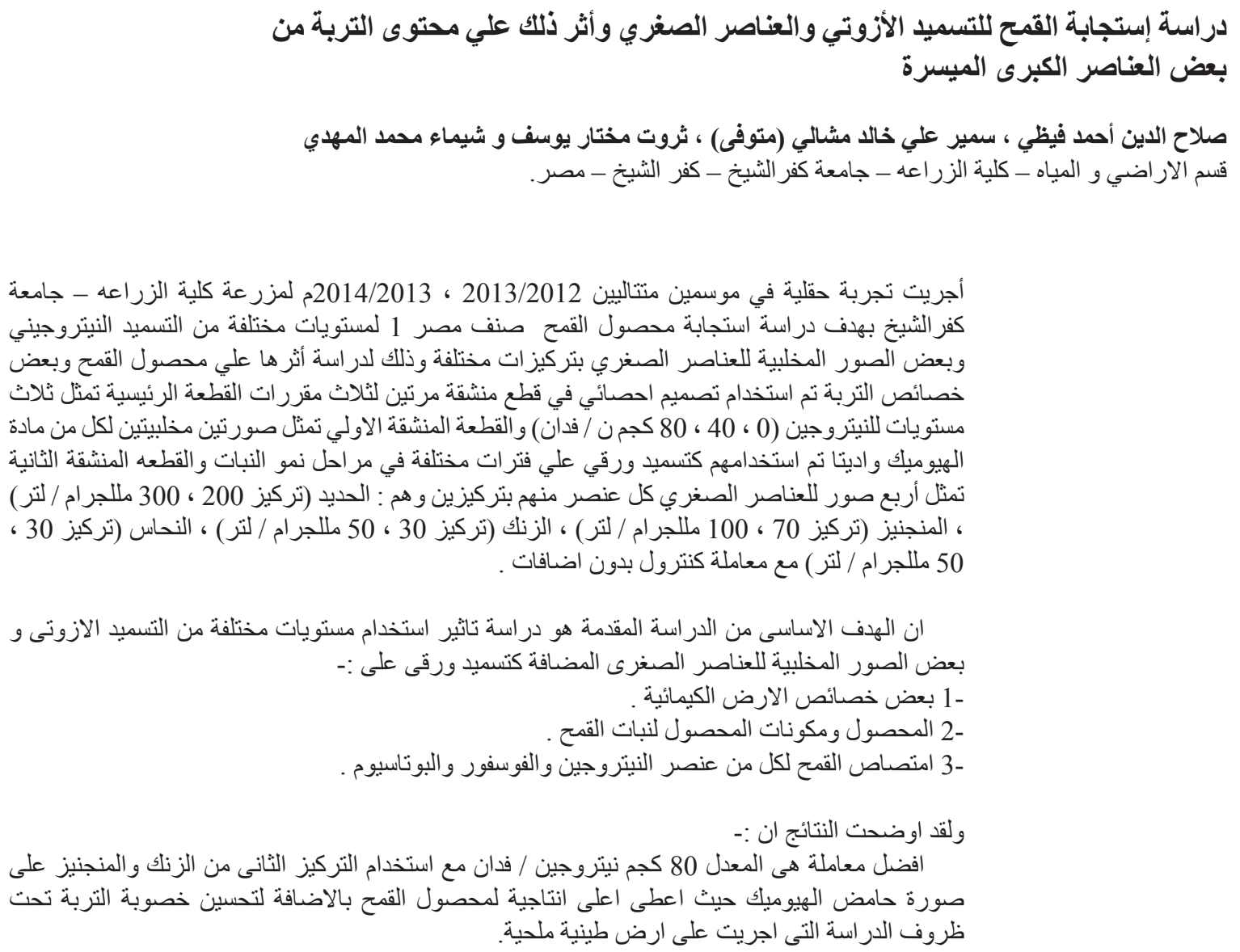